\title{
ТІНЬОВА ЗАЙНЯТІСТЬ ТА ПЕРСПЕКТИВИ ЇЇ ЛЕГАЛІЗАЦІЇ В УКРАЇ̈I
}

\section{ТЕНЕВАЯ ЗАНЯТОСТЬ И ПЕРСПЕКТИВЫ ЕЕ ЛЕГАЛИЗАЦИИ В УКРАИНЕ \\ SHADOW EMPLOYMENT AND PROSPECTS FOR ITS LEGALIZATION IN UKRAINE}

Високий рівень тінізачї ринку прачі вже багато років залишається однією 3 головних загроз соиіальній безпеці, щчо актуалізується в умовах перебудови економіки, вставлення європейських стандартів у галузі оплати та охорони праці, підвищення прозорості суспільно-політичних та економічних відносин. Представлена стаття присвячена вивченню проблеми тіньової зайнятості та визначенню перспектив ї̈ скорочення в Україні. Автором було класифіковано види тіньової зайнятості,визначено сфери господарської діяльності, де вони переважають, описано тотожності та відмінності між ними. В дослідженні описані основні характеристики тіньової зайнятості: стабільно велика ї̈ частка на ринку праці, присутність иьього явища у формальному секторі зайнятості, наявність перспективного джерела легалізачії тіньової зайнятості у вигляді неформальної зайнятості за наймом. Наданий в роботі детальний опис обсягів поширення та характерних рис неформальної зайнятості за наймом може виступати науковим обтрунтуванням заходів державної політики сприяння легалізації зайнятості. В публікації також означено напрями скорочення неформального сектору зайнятості та легалізації праці в Украӥні.

Ключові слова:ринок праці, тіньова зайнятість, неформальна зайнятість, нелегальна зайнятість, незадекларована прачя, прачя за наймом.

Высокий уровень тенизации рынка труда уже много лет остается одной из главных угроз соииальной безопасности, которая актуализируется в условиях перестройки экономики, внедрения европейских стандартов в области оплаты и охрань труда, увеличения прозрачности общественно-политических и экономических отношений. Представленная статья посвящена изучению проблемы теневой занятости и определению перспектив ее сокращения в Украине. Автором были классифицированы виды теневой занятости, определены сферы хозяйственной деятельности, где они преобладают, описанысходные черты и различия между ними. В исследовании описаны основные характеристики теневой занятости: стабильно большая ее доля на рынке труда, присутствие этого явления в формальном секторе занятости, наличие перспективного источника легализачии теневой занятости в виде неформальной занятости по найму. Предоставленное в работе детальное описание масштабов распространения и характерных особенностей неформальной занятости по найму может служсть научным обоснованием мер государственной политики по содействию легализации занятости. В публикации также отмечены направления по сокращению неформального сектора занятости и легализации труда в Украине.

Ключевые слова:рынок труда, теневая занятость, неформальная занятость, нелегальная занятость, незадекларированный труд, наемный труд. 
The significant size of the shadow labour market has been one of the main threats to social security for many years. It is especially pressing problem during the restructuring of the economy, establishing European standards in labour law and wages, increasing the transparency of socio-political and economic relations. The paper is devoted to the problem of shadow employment and the aspects for its reduction in Ukraine. The author has classified the types of shadow employment, defined the economic activities where they predominate, described identities and differences between them. The study describes the main characteristics of shadow employment. They are: stable significant share of the labour market, its presence in the formal employment sector, and promising source of shadow employment legalization - shadow hired labour. The detailed description of distribution and characteristics of informal hired labour may serve as a scientific substantiation of policy measures to promote legalization of employment. This publication also defines directions of reducing the sector of informal employment and ways of the legalization of labour in Ukraine.

Keywords: labour market, shadow employment, informal employment, illegal employment, undeclared work, hired labour.

Вступ. Однією 3 найважливіших характеристик ринку праці в Україні $є$ високий рівень тіньової зайнятості, який зберігається всі роки піi незалежності. Чинники формування та збереження цього явища в перехідних економіках та країнах, що розвиваються, добре описані в зарубіжній науковій літературі [1-2], вивчаються на високому міжнародному рівні в межах діяльності МОП [2-3] та тривалий час аналізуються вітчизняними дослідниками під час вивчення та розробки прикладних аспектів функціонування національного ринку праці [4].

Не зважаючи на визнання того факту, що збереження високого рівня тіньової зайнятості несе низку серйозних загроз економіці та стабільному соціальному розвитку[5 - 6], встановлення магістральних напрямів скорочення тіньової частки ринку праці та розробка практичних заходів, спрямованих на досягнення цієї мети, залишаються пріоритетними практичними завданнями реалізації проактивної державної політики на ринку праці в контексті забезпечення трудоресурсної безпеки. У зв’язку з цим постає питання глибокого вивчення явища тіньової зайнятості,

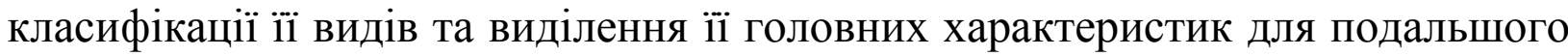
наукового обгрунтування напрямів політики легалізації праці, підвищення іiі безпеки та соціальної відповідальності роботодавців.

Постановка завдання. Метою дослідження розвиток теоретикометодичних засад дослідження тіньової зайнятості, вироблення практичних рекомендацій для реалізації державної політики, спрямованої на скорочення iii обсягів. Головними завдання дослідження $\epsilon$ : встановлення змісту понять «тіньова зайнятість», «нелегальна зайнятість», «неформальна зайнятість», «неспостережувана зайнятість», «незадекларована праця» та відмінностей між ними; надання визначальних характеристик тіньової зайнятості в нашій країні; означення найбільш перспективних політичних кроків у напрямі скорочення обсягів неформального сектору зайнятості.

Методологія. Для реалізації поставлених завдань у роботі було використано комплекс методів теоретичного дослідження та аналізу емпіричних даних. Зокрема, структурно-функціональний аналіз, 
діалектичний метод та метод узагальнення. Для опрацювання масиву статистичних даних використовувалися методи аналізу і синтезу.

Результати дослідження. Найбільш негативним проявом тіньової зайнятості є нелегальна зайнятість. Це діяльність 3 метою отримання прибутку, що має кримінальний характер. До такої зайнятості відносяться як кримінальні правопорушення (торгівля наркотиками, зброєю, проституція) так і порушення законів, що протидіють торгівлі людьми (в тому числі через заборону праці нелегальних мігрантів) та попереджають використання дитячої праці.

Неформальна зайнятість - найбільш поширений вид тіньової зайнятості. До сектору неформальної зайнятості відносяться дрібні незареєстровані виробництва або інші підприємства та організації, де робітники працюють на умовах самозайнятості або зайнятості у сімейному бізнесі. Іноді зустрічаються виробництва 3 мінімальною кількістю залучених сторонніх робітників. Сюди ж відноситься будь-яке виробництво товарів у межах домогосподарств (для власного споживання і для продажу), а також надання послуг особами, які зайняті на роботах в домашніх господарствах (кухарі, прибиральниці, особи, які доглядають за дітьми або людьми літнього віку).

Одним 3 видів неформальної зайнятості $\epsilon$ зайнятість неспостережувана. Як правило, таку назву має неформальна зайнятість у розвинених країнах, де з огляду на уникнення від оподаткування та сплати внесків до фондів соціального страхування, такий вид діяльності розглядається як шахрайство, що посягає існуючий соціальний і правовий лад. Прихованість таких видів діяльності засуджується законом та суспільством. Крім підпільних виробництв до підприємств, де зайнятість носить неспостережуваний характер, сюди відносяться такі, що виробляють товари, заборонені законом (наприклад, окремі медичні препарати). Окремим видом неспостережуваної зайнятості є надання послуг без ліцензії (медичних, юридичних, освітніх).

Особливим видом неформальної зайнятості $\epsilon$ зайнятість незадекларована. За визначенням, прийнятим в Європейському Союзі, незадекларованою працею називається «будь-який прибутковий вид економічної діяльності, що є законним за своєю природою, але так чи інакше приховується від державної влади, зважаючи на особливості звітності в різних країнах» (за Communication from the Commission to the Council, the European Parliament, the European Economic and Social Committee and the Committee of the Regions - Stepping up the fight against undeclared work). Однак сюди не включаються ті види діяльності, що не повинні декларуватися за законом, як то: виробництво в межах домогосподарств та волонтерська робота. До незадекларованої зайнятості залучені як робітники, які працюють на офіційних виробництвах без належного оформлення (як постійні, так i тимчасові), так i працівники, які $\epsilon$ офіційно зайнятими на інших підприємствах, але одночасно залучені до неформального сектору для отримання додаткового прибутку. За законодавством СС, незадекларованою 
є праця всіх працівників, заробітна плата яких не декларується 3 метою мінімізації сплати податків та внесків до фондів соціального страхування таких, які повністю або частково (за винятком мінімальної за законодавством iii частини) отримують заробітну плату «в конвертах».

3 юридичної точки зору всі зазначені види зайнятості не співпадають у своїй сутності та розрізняються за тяжкістю порушення різних видів законодавства (кримінального, адміністративного, податкового, соціального i т.д.).

Протизаконна спрямованість нелегальної зайнятості обумовлює іï повністю прихований характер, що виключає будь-які претензії влади на сплату податків та внесків до фондів соціального страхування. Близькою до нелегальної може виступати неспостережувана зайнятість у випадках, коли йдеться про виробництво товарів або надання послуг, заборонених законом. У випадку з неформальною зайнятістю частіше за все відбувається планове уникнення від сплати податків та внесків до фондів соціального страхування. При незадекларованій зайнятості вносяться платежі за «офіційну частку» заробітної плати, якщо має місце їі часткова легалізація.

У питанні реєстрації робітників зміст цих термінів майже збігається. Головна різниця у тому, що при нелегальній зайнятості відсутня реєстрація уразливих категорій робітників, зайнятість яких регулюється спеціальними нормами законодавства (дітей та нелегальних мігрантів). При неформальній та неспостережуваній зайнятості офіційна реєстрація працівників відсутня. Незадекларована зайнятість передбачає реєстрацію тих робітників, які отримують свою заробітну плату частково офіційно, частково - «на руки».

Різні види тіньової зайнятості помітно відрізняються за порушенням законодавства в галузі охорони праці. Так, при неформальній та неспостережуваній зайнятості має місце їх звичайне ігнорування. При нелегальній зайнятості крім звичайного законодавства у цій сфері порушуються спеціальні закони, спрямовані на захист уразливих категорій працівників (дітей та нелегальних мігрантів). При незадекларованій зайнятості порушення норм трудового законодавства стосується тих категорій працівників, які повністю отримують зарплату «у конвертах» і не $\epsilon$ офіційно зареєстрованими як наймані працівники.

Досить помітно всі види тіньової зайнятості відрізняються за своїм внеском у функціонування тіньової економіки. Так, нелегальна зайнятість $є$ невід'ємною частиною кримінальної діяльності та характерним явищем при використанні дитячої праці та праці нелегальних мігрантів. Водночас неспостережувана зайнятість не носить кримінального характеру, однак включає в себе такі види правопорушень як виробництво товарів та послуг, що заборонені законом, та надання ліцензованих послуг. Неформальна та незадекларована зайнятості $\epsilon$ найбільш «чистими перед законом» 3 точки зору ведення господарської діяльності, адже будь-яка 3 них не передбачає жодних дій, заборонених законом.

Жоден з видів тіньової зайнятості не надає найманим (без офіційного статусу) працівникам правових інструментів боротьби за свої економічні та 
соціальні права, а отже - розширює можливості для зловживань у цій сфері 3 боку роботодавців.

Головними характеристиками тіньової зайнятості є:

1. Стабільність їі рівня.На рис.1 показано, що показник долі населення, зайнятого у неформальному секторі, $є$ більш стійким до макроекономічних коливань, ніж показник рівня тіньової економіки (вираженого у \% до ВВП). Так, не зважаючи на суттєві зміни у макроекономічному середовищі в 2009 2015 рр., зайнятість у неформальному секторі залишалася всі ці роки відносно стабільною і ії несуттєве зростання в 2014 - 2015 рр. пов'язане великою мірою зі зміною методології вимірювання цього показника Держстатом.

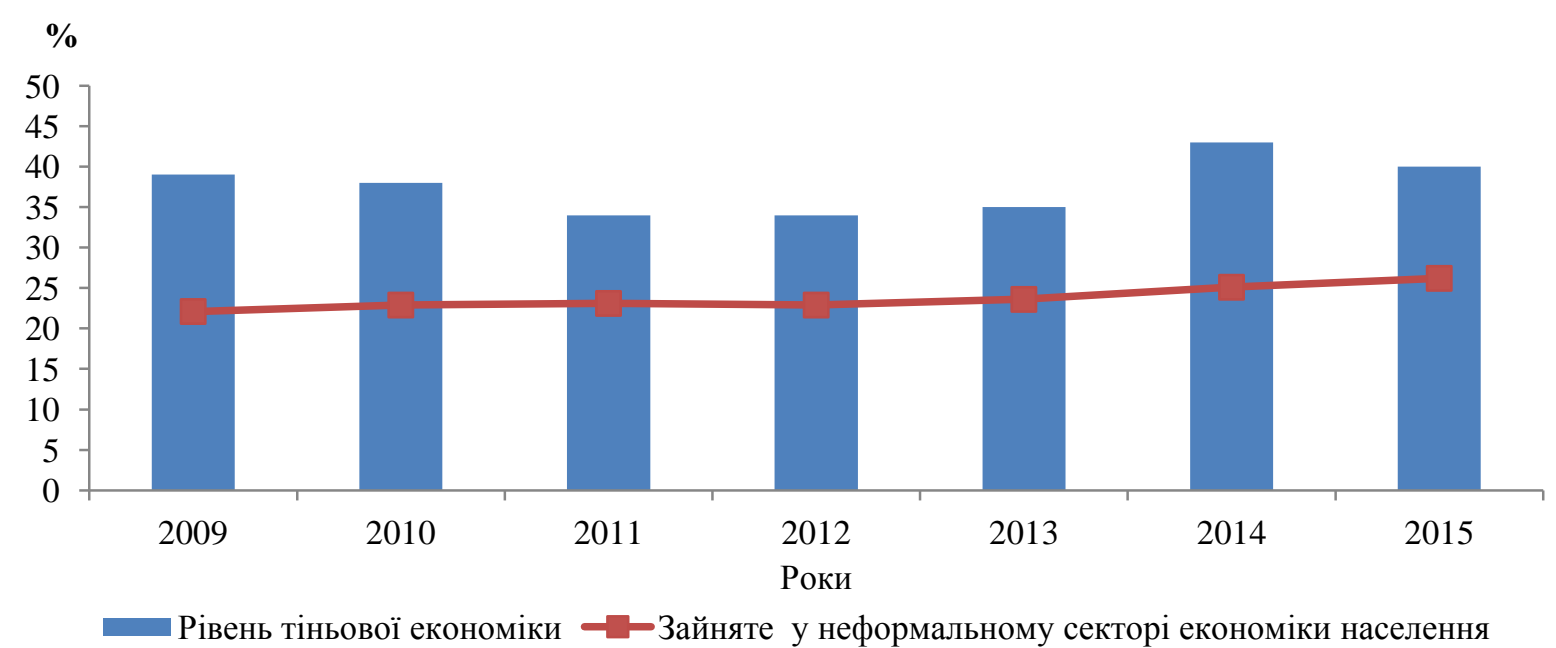

Рис. 1. Рівень тіньової економіки (у \% до ВВП) та доля населення, зайнятого у неформальному секторі (\%), в $2009-2015$ рр.

Джерело: Міністерство економічного розвитку і торгівлі Украӥни [7] та Держстат.

2. Присутність у формальному секторі.Частіше за все в ньому така зайнятість носить характер неналежної реєстрації трудових відносин. У випадку $з$ найманими працівниками ії характеристики та поширеність в залежності від приналежності до певного сектора економіки дещо різняться. Аналіз статистичних даних свідчить про те, що в середньому серед усіх зайнятих в формальному секторі тільки приблизно 5,64\% працівників працюють «в тіні», в той час як серед найманих працівників неформального сектору таких більше половини - 66,5\% [4]. У неформальному секторі така зайнятість сконцентрована більшою мірою на малих підприємствах $(94 \%$ найманих працівників працюють на підприємствах, де зайнято до 10 осіб включно), водночас у формальному вона має порівняно рівномірну поширеність, хоча тенденція падіння частки неформально зайнятих осіб зі збільшенням розміру підприємства прослідковується чітко (рис. 2). 


\section{Формальний сектор}

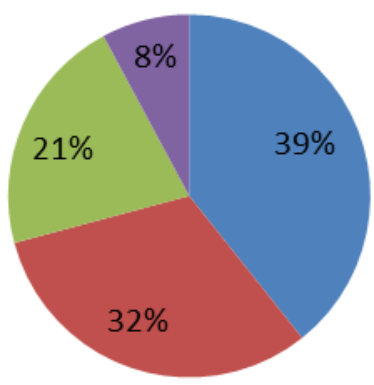

\section{Неформальний сектор}

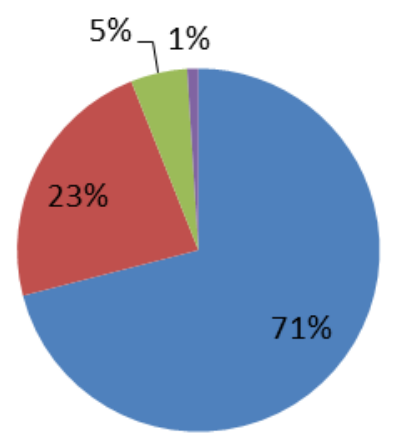

- До 5 працівників

- 5-10 працівників

—11-50 працівників

- Більше 50 працівників

Рис. 2. Частки неформально зайнятих найманих працівників в формальному та неформальному секторах за розмірами підприємств, \%

Джерело: за аналітичною запискою для уряду України «Обсяги та основні характерні риси неформальноі зайнятості в Україні», О.Купець, 2011 р. [4].

Розглянемо рівні неформальної зайнятості найманих працівників в формальному і неформальному секторах в залежності від виду економічної діяльності. В обох випадках основними видами господарської діяльності, де сконцентрована неформальна зайнятість, є: торгівля та ремонт, будівництво, сільське господарство, промисловість. Заслуговує на увагу той факт, що у неформальному секторі тіньова зайнятість найманих працівників найбільшою мірою сконцентрована в будівництві $(43,94 \%$ від усього обсягу такої зайнятості), в той час як у формальному секторі - в торгівлі та ремонті (36, 84\%). Варто також зазначити, що концентрація неформально зайнятих працівників промисловості у формальному секторі значно вища, ніж у неформальному (11,93\% проти 6,28\%). Натомість в неформальному секторі більша, ніж у формальному, доля таких працівників в сільському господарстві $(13,81 \%$ проти $8,88 \%)$ (таблиця).

Таблиия

Розподіл тіньової зайнятості найманих працівників у формальному та неформальному секторах за видами економічної діяльності в 2009 р., \%[4]

\begin{tabular}{|c|c|c|}
\hline & $\begin{array}{l}\text { Формальний } \\
\text { сектор }\end{array}$ & $\begin{array}{l}\text { Неформальний } \\
\text { сектор }\end{array}$ \\
\hline \multicolumn{3}{|l|}{ Вид економічної діяльності } \\
\hline Сільське господарство & 8,88 & 13,81 \\
\hline Промисловість & 11,93 & 6,28 \\
\hline Будівництво & 25,57 & 43,94 \\
\hline Торгівля та ремонт & 36,84 & 22,29 \\
\hline Діяльність готелів та ресторанів & 5,2 & 1,43 \\
\hline Діяльність транспорту та зв'язку & 5,2 & 2,91 \\
\hline $\begin{array}{l}\text { Фінансова діяльність; операції з нерухомим майном, } \\
\text { оренда, інжиніринг та надання послуг підприємцям }\end{array}$ & 1,86 & 0,34 \\
\hline Освіта & 0,4 & 0,1 \\
\hline Охорона здоров'я та надання соціальної допомоги & 0,37 & 0,15 \\
\hline Надання комунальних та індивідуальних послуг & 3,47 & 2,54 \\
\hline
\end{tabular}


Приватні домогосподарства з найманими

0,28

6,21

працівниками

Джерело: за аналітичною запискою для уряду України «Обсяги та основні характерні риси неформальної зайнятості в Україні», О.Купець, 2011 р. [4].

3. Наявність перспективного джерела легалізації у вигляді неформальної зайнятості за наймом. Така зайнятість має певні особливості, порівняно з загальним сектором неформальної зайнятості. Так, розрив між долею неформально зайнятих найманих працівників 3 міст та сільської місцевості є значно меншим (8,7\% та 14,6\% в 2013 р.), ніж розрив між долями всіх неформально зайнятих представників різних місцевостей, незалежно від статусу зайнятості (10\% та 46,4\% відповідно у тому ж році - за даними Держстату). Головним чином остання цифра випливає з надвисокого рівня неформальної самозайнятості в домашніх господарствах у сільській місцевості.

Крім того, в неформальну зайнятість найманих працівників залученість чоловіків є двічі вищою, ніж залученість жінок (13\% проти 6,7\% в 2013 р.). Водночас по неформальному сектору в цілому рівні залученості представників різних статей є більш близькими (22,1\% для жінок і 24,9\% для чоловіків - за даними Держстату). Невелика різниця в останніх цифрах випливає саме 3 більшого рівня залученості неформальних працівників-чоловіків до формального сектору. Так, зайнятість найманих жінок-працівників більше ніж наполовину (на 54\% - в 2009 р.) сконцентрована у торгівлі, що належить переважно до неформального сектору. Водночас чоловіки зайняті як представники найпростіших професій у промисловості $(13,41 \%)$, сільському господарстві $(6,69 \%)$, в якості водіїв $(7,33 \%)$, будівельників та ремонтників споруд (6,79\%), мулярів та штукатурів (12,32\%) та на ін. роботах у формальному секторі [4].

В неформальній зайнятості за наймом (на відміну від неформальної зайнятості в цілому) також спостерігається падіння рівня залученості до неї зі зростанням віку учасників трудових відносин.

Іншою важливою інформацією з аналізу тіньової зайнятості найманих працівників в міжпоселенському розрізі є дані про сфери прикладання праці для представників різних місцевостей. Так, більше ніж половина $(63,61 \%)$ сільських жителів 3 відповідним статусом були у 2009 р. зайняті у будівництві $(37,36 \%)$ та сільському господарстві $(26,25 \%)$. Водночас майже 2/3 (сукупно) неформально зайнятих найманих працівників 3 міст працювали в сферах торгівлі та ремонту (40\%) та в будівництві $(30,79 \%)$.

Аналіз даних про характеристики тіньової зайнятості за наймом в різних сферах економіки свідчить про наступне: 90,8\% зайнятості найманих працівників у приватних домогосподарствах складала ії неформальна частина, i цей сектор є безсумнівним лідером за долею такої зайнятості. В будівництві рівень неформальної зайнятості найманих працівників складав 39,4\%. В сфері торгівлі та ремонту - 17,3\%, в готельному і ресторанному бізнесі - 16,6\% (сукупно). Рівень неформальної зайнятості найманих працівників в сільському 
господарстві (яке в цілому складало 66,6\% всього неформального сектора зайнятості в 2009 р.) склав в цей період 13,3\%.

Скорочення неформального сектору зайнятості та легалізація праці в Україні можливі лише за умови проведення проактивної політики на ринку праці та реалізації спеціальних заходів соціально-економічної політики сприяння легальній зайнятості. До таких відносяться:

1. Розробка та впровадження ефективної системи прогнозування попиту на робочу силу на національному рівні через вивчення ऑii майбутнього руху в регіональному розрізі на основі науково обгрунтованих передбачень змін у територіальних структурах економіки.

2. Створення ефективних законодавчих стимулів для залучення широких верств населення до роботи у формальному секторі економіки (податкові пільги для сімей з дітьми, високий рівень соціального захисту, розбудова другого та третього рівні в пенсійної системи і т.п.).

3. Забезпечення сприятливих інституціональних умов для «перетікання» неформальної самозайнятості у сферу дрібного і малого підприємництва: зменшення зарегульованості економічної діяльності приватних підприємців, розширення для них доступу до кредитних ресурсів, створення податкових пільг (в тому числі тимчасових) у тих сферах господарської діяльності, розвиток яких $\epsilon$ пріоритетним для держави.

4. Розробка та впровадження ефективного державного механізму податкового стимулювання роботодавців до офіційного найму осіб 3 низьким рівнем конкурентоспроможності на ринку праці: осіб з низьким рівнем освіти, молодих людей без досвіду роботи, жінок 3 дітьми, людей передпенсійного віку.

5. Скорочення сектору нелегальної зайнятості по двох напрямах: боротьба 3 організованою злочинністю та сприяння підвищенню рівня оплати інтенсивної та фізично виснажливої праці у відповідних сферах зайнятості.

Висновки. Наукова новизна результатів дослідження полягає у розвитку теоретико-методичних засад дослідження тіньової зайнятості та розробленні практичних рекомендацій з мінімізації їі негативного впливу на стан трудоресурсної безпеки. Практичне значення проведеного дослідження полягає у тому, що рекомендації щодо скорочення неформального сектору зайнятості та легалізації праці можуть бути використані у діяльності центральних органів державної влади, органів місцевого самоврядування, при розробці національних, регіональних та галузевих програм розвитку.

Подальші дослідження тіньової зайнятості мають бути спрямовані за вимірювання ii обсягів у грошовому еквіваленті та визначення найбільш економічно обгрунтованих напрямів легалізації неформальної праці. 


\section{Література:}

1. Gunter I. Informal Employment in Developing Countries. Opportunity or Last Resort? / I. Gunter, A. Launov // Journal of Development Economics. - 2012. - Vol. 97.

2. Baccheta M. Globalization and Informal Jobs in Developing Countries / M. Bacchetta, Ekkehard Ernst. - Geneva: ILO/WTO, 2009. - 187 p.

3. Daza J.L. Informal Economy, Undeclared Work and Labour Administration/ J.L. Daza. Geneva: ILO, 2005. - 67 p.

4. Купець О. Обсяг та основні характерні риси неформальної зайнятості в Україні / О. Купець. - Вашингтон: Світовий Банк, 2011. - 32 с.

5. Надрага В.I. Соціальні ризики в трудовій сфері: дис. ... доктора економ. наук: 08.00.07/ Надрага Василь Іванович. - Київ: Інститут демографії та соціальних досліджень ім. М.В. Птухи, 2016. - 472 с.

6. Яценко Л. Ризик поширення та шляхи мінімізації тіньової зайнятості в Україні / Л. Яценко, Л. Якушенко // Аналітична доповідь. Серія «Соціальна політика», (№23), 2015. $12 \mathrm{c.}$

7. Міністерство економічного розвитку і торгівлі України Тенденції тіньової економіки в Україні I квартал 2016 року [Електронний ресурс]. - Режим доступу: http://www.me.gov.ua/Documents/List?lang=uk-UA\&id=e384c5a7-6533-4ab6-b56f-

50e5243eb15a\&tag=TendentsiiTinovoiEkonomiki 